\title{
MODELING CONTROL OF AUTOMATIC VOLTAGE REGULATOR WITH PROPORTIONAL INTEGRAL DERIVATIVE
}

\author{
Hestikah Eirene Patoding ${ }^{1}$, Eodia T. Lobo ${ }^{2}$, Matius Sau ${ }^{3}$ \\ ${ }^{1}$, Electrical Engineering, Paulus Chrystian University of Indonesia, Makassar, Indonesia \\ ${ }^{2}$, Electrical Engineering, Paulus Chrystian University of Indonesia, Makassar, Indonesia \\ ${ }^{3}$, Electrical Engineering, Paulus Chrystian University of Indonesia, Makassar, Indonesia
}

\begin{abstract}
The Automatic Voltage Regulator (AVR) cannot respond generator output voltage quickly resulting in drop voltage and can be affected to the electrical system. AVR controller simulation model created in power system based on real data from National Electricity Company (PLN) ( Tello Power Plant Makassar case). AVR controller response time under normal conditions has the oscillation time of about 9 seconds and response time when loaded is about 15 seconds. Resulting unstable voltage in the system follows load changes. With the addition of Proportional Integral Derivative (PID) controllers acquired a controlling response time to changing loads faster and system voltage will change the voltage stability limit of $\pm 5 \%$ of nominal voltage. AVR controller with PID is very suitable for controlling the voltage of power generation system due to changes in load.
\end{abstract}

Key Words: Automatic Voltage Regulator, Proportional Integral Derivative

\section{INTRODUCTION}

The automatic control is needed in operations in the industry to handle the pressure, temperature, humidity, viscosity, flow production process, working with machine tools, handling and assembly of mechanical parts in manufacturing industry, and so on. Advances in the theory and practice of automatic control facilitates in obtaining performance of dynamic systems, elevate the quality and reduce production costs, heightens production rate, reduce routine tasks and tedious to be done by humans, and so on.

The operation of electric power systems, load changes and abnormal conditions cause changes in the frequency and scheduling of power in every area. Such changes, resulting in changes in the amount of voltage (voltage magnitude). It can be fatal in a system, if there is additional reactive power load for the generator terminal voltage will drop. To overcome this use the generator excitation control using AVR. The AVR quickly response in the event of disruption or change in system load [5].

When the generator is operated (at a frequency of $50 \mathrm{~Hz}$ ) with a fixed output voltage magnitude), it will be spinning at a relatively constant speed. However, the rotation speed of the generator is affected by the load, when the load increases, the speed will drop, and vice versa. If the generator is intended to operate at a constant speed when load is changed, we need a controller to adjust the input frequency. Changes in the frequency of the system can occur due to load shedding, for the case Sulselbar Systems [9].

So that will be needed to research and analysis on the fluctuating load changes. Changing the rotation generator resulting voltage fluctuations in the bus system. Therefore, this study will make and analyze a model to regulate the speed of the generator rotation, so that the voltage in the system can be managed in a stable condition correspond to existing limitations.

\subsection{Controller System [3]}

Operation of energy systems is growing rapidly at this time both in science and technology as well as in the industrial world. These developments felt also the supplier of electrical power (PLN) to regulate its supply to the load. This can be seen with the use of well control equipment in the generation, substation or distribution substation.

Control equipment for the generation are usually used to regulate the supply of active and reactive power. Load changes occur very influential on changes in the frequency and voltage. Rise and fall of frequency dependent active power changes, so does the voltage depending on changes in reactive power. This situation opens the mind to the engineers particularly in the field of power systems to find a solution. One of the solutions in managing change in reactive power load in order to use AVR generator voltage stays constant, however, can not regulate steady-state error due to the dynamic response, because it takes control device that is capable of eliminating the steady state error is controlling Proportional, Integral and Derivative (PID controller)

\subsection{Automatic Voltages Regulator (Avr) [5]}

The rules of AVR is to maintain the generator terminal voltage magnitudes at the specified level. AVR system consists of four (4) main components there are amplifier, exciter, generator and sensors. The mathematical model and transfer functions can be to linear taking into account the time constant and ignoring saturation or other nonlinear. There are can be shown in Fig-1. 


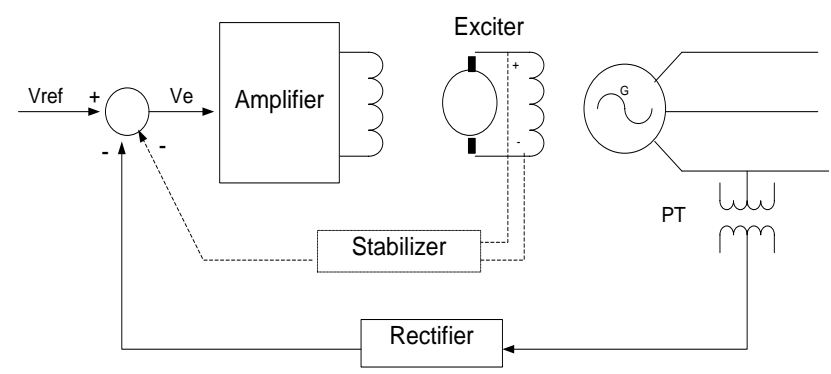

Fig-1: General Model of AVR [4]

\section{Amplifier Model [5]}

Amplifier models expressed by a gain with $\mathrm{K}_{\mathrm{A}}$ symbol and time constant with $\tau_{\mathrm{A}}$ symbol. Transfer function is:

$$
\frac{\operatorname{VR}(s)}{\operatorname{Ve}(s)}=\frac{K_{A}}{1+\tau_{A} s}
$$

$$
\text { with: Value of } \mathrm{K}_{\mathrm{A}} \text { ranged from } 10 \text { to } 400
$$

Time constant $\tau_{\mathrm{A}}$ ranged 0,02 to 0,1 seconds

\section{Exciter Model [5]}

The transfer function of a modern exciter can be expressed by a gain with $K_{E}$ symbol and single time constant with $\tau_{\mathrm{E}}$ symbol, then the transfer function is:

$$
\frac{V F(s)}{V R(s)}=\frac{K_{E}}{1+\tau_{E} s}
$$

with: Value of $K_{\mathrm{E}}$ range 10 to 400

Time constant $\tau_{\mathrm{E}}$ between 0,5 to 1 second

\section{Generator Model [5]}

In a linearized form, the relationship transfer function of voltage terminal generator with voltage field can be expressed by a gain $\left(\mathrm{K}_{\mathrm{G}}\right)$ and time constant $\left(\tau_{\mathrm{G}}\right)$. The transfer function is :

$$
\frac{V t(s)}{V F(s)}=\frac{K_{G}}{1+\tau_{G} s}
$$

This constant depends on the load, can be vary ranged from 0,7 to 1.0 and ranged 1,0 to 2,0 from full load to zero load.

\section{Sensor Model [5]}

Sensor are modeled with a simple first order transfer function, written by:

$$
\frac{V s(s)}{V t(s)}=\frac{K_{R}}{1+\tau_{R} s}
$$

with: Value of $\tau_{\mathrm{R}}$ ranged from 0,001 to 0,06 second.

\subsection{Pid Controller [5]}

Proportional Integral Derivative (PID) controller is a combination controller of the Proportional, Integral and Derivative. Each combination has advantages and disadvantages so that this controller can be used as needed. In the electric power system PID controller can be used to cope with large load changes and sudden. Integral mode is used to eliminate offset proportional and derivative mode is used to reduce the tendency towards oscillation and provide action control that anticipate changes in signaling faults. PID controller is a type of continuous controller composed of three types of control continuous basis namely Proportional controller, Integral controller and Differential controller. Mathematically the PID controller can be written:

$$
m(t)=K_{p} e(t)+K_{I} \int_{0}^{t} e(t) d t+K_{D} \frac{d e(t)}{d t}
$$

with:

$m(t)=$ compensator input

$e(t)=$ compensator output

Laplace transform of the equation obtained transfer function PID controller as follows ${ }^{[6]}$ :

$$
M(s)=\left(K_{p}+\frac{K_{I}}{S}+K_{D} s\right) E(s)
$$

or

$$
G(s)=\frac{M(s)}{E(s)}=K_{p}+\frac{K_{I}}{S}+K_{D} s
$$

with :

$\mathrm{K}_{\mathrm{P}}=$ proportional constant reinforcement

$\mathrm{K}_{\mathrm{I}}=$ integral constant reinforcement

$\mathrm{K}_{\mathrm{D}}=$ differential constant reinforcement

Mathematical equations forms of PID controller that are arranged in parallel can be expressed in the form of a block diagram such as below:

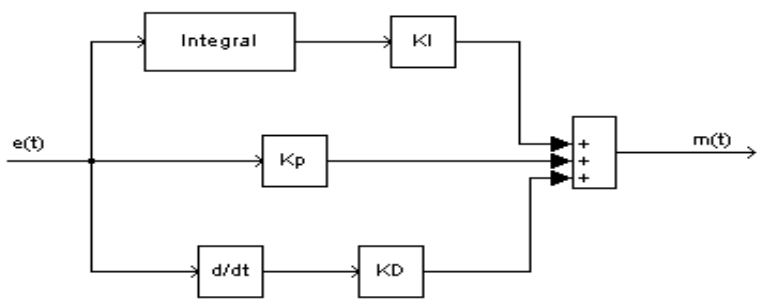

Fig-2: Block diagram of PID mathematically

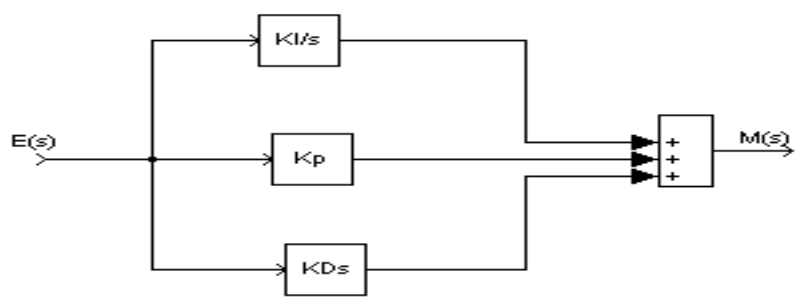

Fig-3: Block diagram of PID with Laplace

\section{REASERCH METHOD}

\subsection{Stage Of Research}

[1]. To Collects information related PID controllers, AVR control and generation systems, including down load files from the Internet (Information form secondary data from the PLN and study literature).

[2]. Collect daily data generation based on peak load operation day and night. 
[3]. Grouping the data loads then processed within Microsoft Excel.

[4]. Creating a model of control by using simulink within Matlab R14 version 7.8. This software is very good in preparing and making the model so that research can be done in several steps:

[5]. Taking the necessary models such as voltage reference with a step function models on Continuous Functions within Simulink.

[6]. Creating a model for the process (the system to be controlled) in the form of Laplace equation is then connected to the reference voltage as the reference input of the system to be controlled.

[7]. Creating the sensor models to detect the output voltage as a result of processes that do not cross the limits of the existing voltage.

[8]. Create a view of output voltage in graphical form by installing a function scope on the output voltage.

[9]. The simulation results of this control system will be tested by analyzing the equation formed by existing models using Routh criteria then calculate the magnitude of the control parameters then compute the output voltage generator.

\subsection{Location of Research}

This research was conducted at the office of PT. PLN (Persero) Power Unit Tello, Makassar, from April until May 2015.

\subsection{Research Instrument}

The instrument used in this study is the hardware and software. Hardware includes a set of computers that are compatible with the software used, while the software include Matlab Simulink. To simulation of the AVR controller when normal conditions and load conditions. Microsoft Excel helpful in the processing of the initial data and graphs. Microsoft Visio is a tool to create a block diagram or flow chart.

\subsection{Model Used}

In this study, power represented by a generator on the Gas Power Plant is modeled as a resource and equipped with control equipment namely AVR and PID to get a quick response time within controlling the voltage changes due to changes in system load.

\subsection{Research Design}

Simulations model of the research design is described as follows:

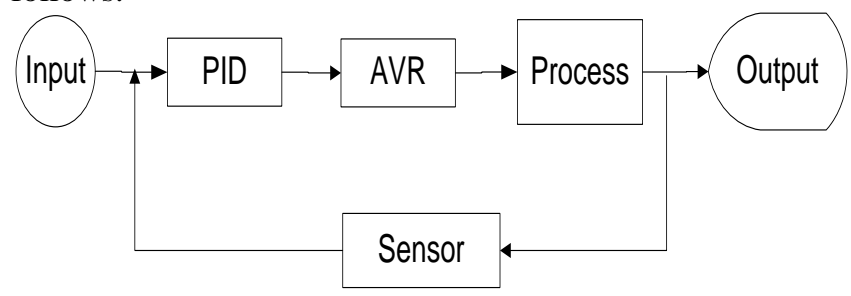

Fig-4: Block diagram of AVR with PID Controller Caption 4 :
- Input Block: This block contains varying data load.

- AVR Block: This block contains control models voltage regulator is general used, but the time response is not fast.

- $\quad$ PID Block This block contains control model voltage regulator that works faster when the reactive load changes.

- Process Block: This block contains a combination of both models AVR control and PID.

- Sensor: This block contains a detection tool in determining the response time of the control models.

- Output Block: This block contains the display output voltage changes with time to variying load on the system.

- $\quad$ The arrow indicate the direction of process control.

\section{RESULTS AND ANALYSIS}

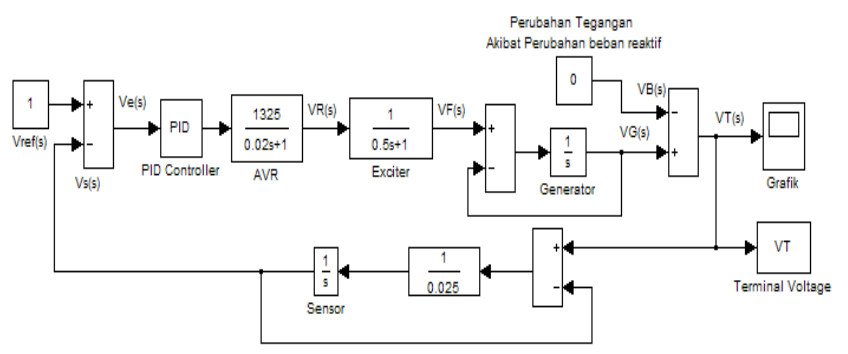

Fig-5: AVR simulation with proportional control on Normal Conditions (Load Changes $=0$ due to changes Reactive Power $=0$ )

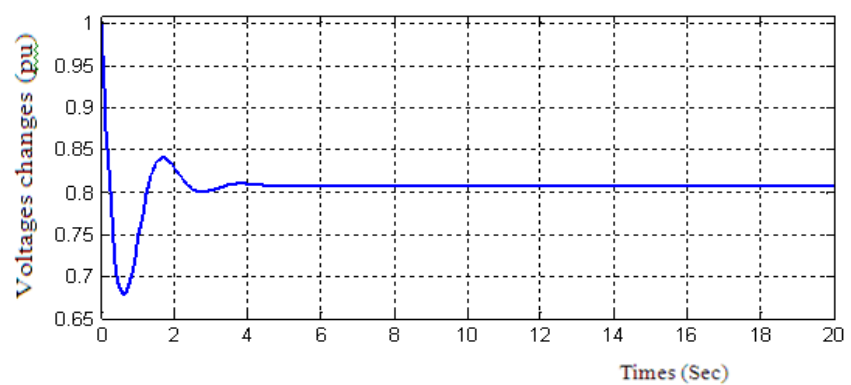

Fig-6: Relation output voltage versus time with $\mathrm{Kp}=$ 0.00318671

In Fig- 6 for $\mathrm{Kp}=0.00318671$ to the reference voltage 1.0 $\mathrm{pu}$, the magnitude of output voltage generator before there is an interruption of $0.808517 \mathrm{pu}$ to overshoot by $25 \%$ and setting time 2.63476 seconds.

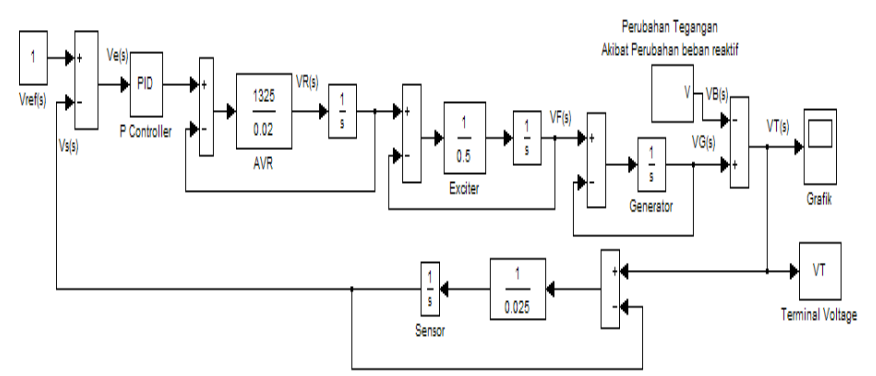

Fig-7: AVR simulation with P controller on the load condition. 

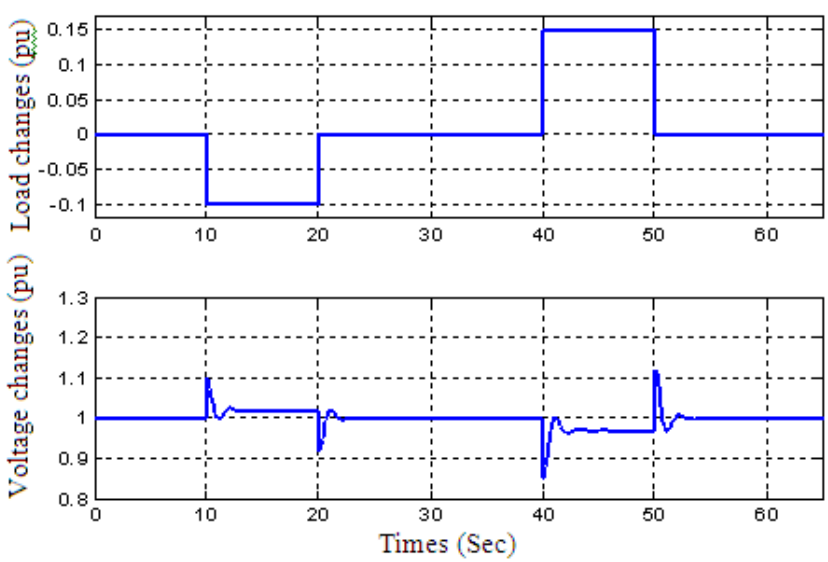

Fig-8: Simulation AVR with P controller when there disturbance.

The voltage changes $(\Delta \mathrm{V})$ decreased by $0.1 \mathrm{pu}$ and $\Delta \mathrm{V}$ increased by 0.15 pu with $\mathrm{Kp}=0.00318671$
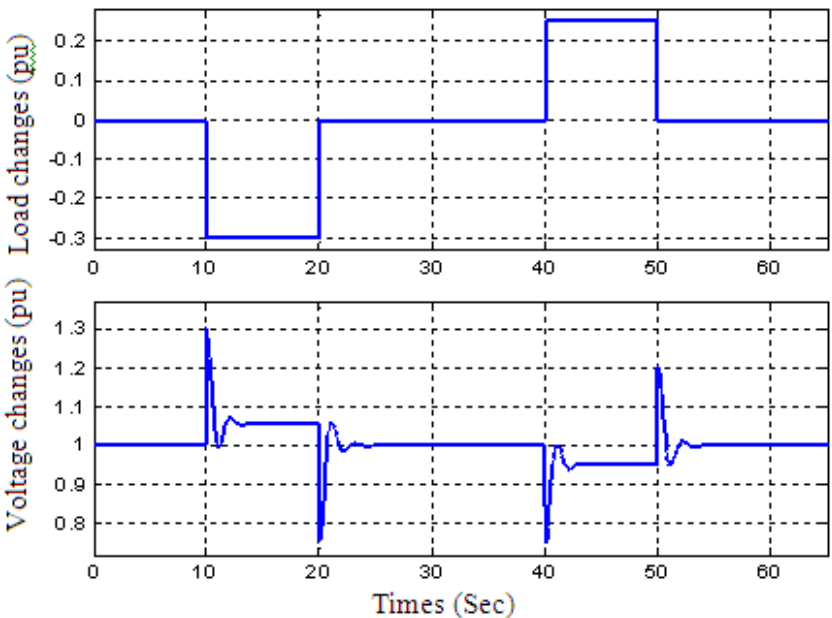

Fig-9: Results of simulation AVR with P controller when there disturbance.

The voltage changes $(\Delta \mathrm{V})$ decreased by 0.3 pu and $\Delta \mathrm{V}$ increased by 0.25 pu with $\mathrm{Kp}=0.00318671$

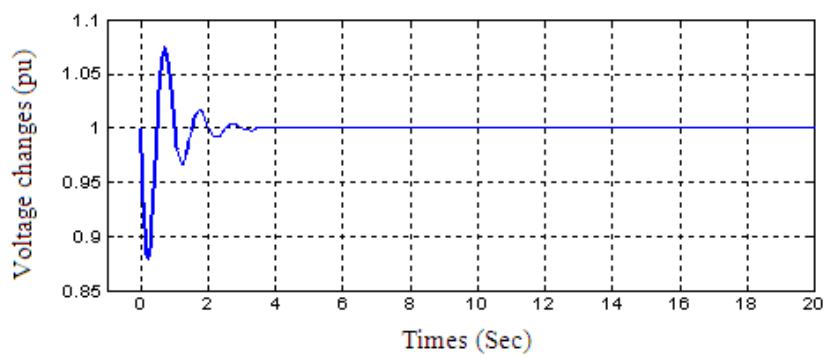

Fig-10: Results of simulation AVR with PID controller on normal condition with $\mathrm{Kp}=0.0161354, \mathrm{Ki}=0.04186340$ and $\mathrm{Kd}=0.00155477$

From Fig-10 above can be explained that the voltage referansi $1.0 \mathrm{pu}$, the output voltage of the generator using the AVR with a PID controller is equal to a voltage of 11.5 $\mathrm{KV}$ or $1.0 \mathrm{pu}$. This situation occurs with $\mathrm{P}$ constant $(\mathrm{Kp})=$ 0.0161354, I constant $(\mathrm{Ki})=0.0418634$ and D constant $(\mathrm{Kd})$ $=0.00155477$.
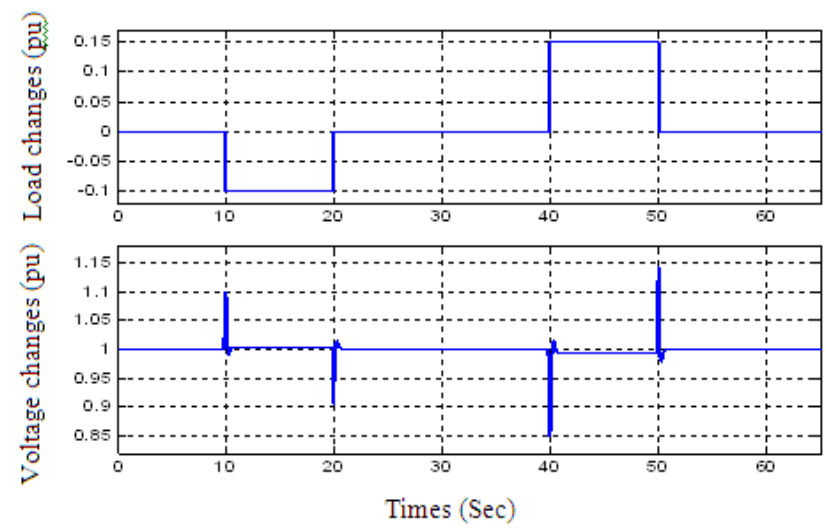

(a) Load decreased by 0.1 pu and load increase by 0.15 pu
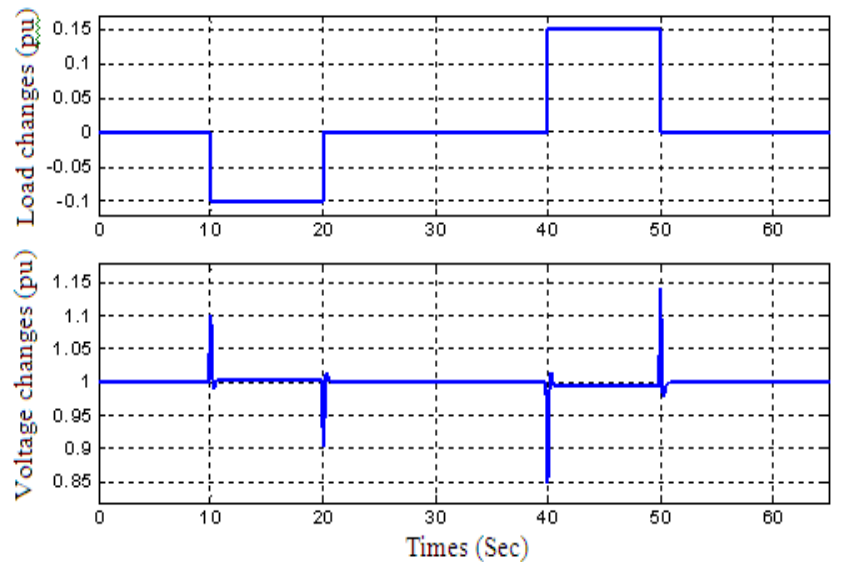

(b) Load decreased by $0.2 \mathrm{pu}$ and load increase by $0.25 \mathrm{pu}$

Fig-11: Results of simulation AVR with PID controller optimum design in the case of disturbance to $\mathrm{Kp}=$ $0.0161354, \mathrm{Ki}=0.01815$ and $\mathrm{Kd}=0.00359$

The addition of a PID controller on the AVR, the time used of AVR in restoring voltage on the voltage stability to be very short, despite experiencing oscillation or swing just one time and then returned to the point of stability. This is done by setting the double-zero value to get the $\mathrm{Kp}, \mathrm{Ki}$ and $\mathrm{Kd}$ are optimum.

The simulation results show that the time used PID controllers to returns the voltage to a stable position is shorter with a maximum overshoot of $25 \%$ compared to using the AVR with $\mathrm{P}$ controller, the time used to restore the voltage in stable condition for a long time at the same maximum overshoot of $25 \%$.

Thus it can be explained that PID controller optimum design is better than the $\mathrm{P}$ controller on AVR system to Tello power plant case.

\section{CONCLUSIONS}

1. The right location for the installation of a PID controller in the AVR system installed after load changes input (before the AVR system) so that the load changes the affect voltage can be set. AVR's performance becomes lighter in controlling the voltage on the existing tolerance.

2. P and PID controllers conducted in disturbance conditions or changes in load, indicated that the PID controller is better than the P controller to control the voltage in times of load changes. 


\section{ACKNOWLEDGEMENT}

This study is a Research Competitive Grant Number: DIPA 1518/K9/AK.03/2015 dated $10^{\text {th }}$ April 2015, for that we would like to thank DitLitabmas that gives research funding.

\section{REFERENCES}

\section{Texbooks :}

[1]. Aris Rakhmadi, TaufiqSawaludin, Maret 2004. Pengendali PID Berbasis PLC Modicon TSX Micro 3722 Untuk Mengatur Kecepatan Motor Induksi Tiga Fase, Teknik Elektro Universitas Muhammadiyah Surakarta, Jurnal Teknik Elektro dan Komputer Emitor Vol. 4, No. 1, accessed on Mei 20, 2010

[2]. Charles L. Phillips, Alihbahasa Prof. R. J. Widodo, 1997. SistemKontrol, Dasar-dasar, Prenhalindo, Jakarta.

[3]. Charles L. Phillips, 1996. Feedback control system, Prentice Hall

[4]. Charles L. Phillips, 1996. Alihbahasa Prof. R. J. Widodo, 1997. Sistem Kontrol, Lanjutan, Prenhalindo, Jakarta

[5]. Hadi Saadat, 1999. Power system Analysis, McGraw Hill

[6]. Katsuhihiko Ogata, 1997. Modern Control Engineering, Third Edition, Prentice Hall

[7]. Prabha Kundur, 1994. Power system stability and Control, McGraw Hill

[8]. Robert H. Bishop, 1997. Modern control systems Analysis and design using Matlab and simulink, Addison Wesley Longman Inc, Canada

\section{Journal:}

[1]. Matius Sau, 2009. Perubahan frekuensi sistem dapat terjadi akibat pelepasan beban, untuk kasus Sistem Sulselbar, Jurnal Adiwidia, Makassar

[2]. N. Rengarajan, ANN based design of governor control, Principle, Vivekananda Institute of Engineering \& technology, India, accessed on September 27, 2012

[3]. Zwe Lee Gain, June 2004. A particle swarm optimization approach for optimum design of PID controller in AVR system, IEEE Trans. On Energy conversion, Vol. 19 No. 2.

\section{Internet:}

Http://en.wikipedia.org/wiki/PID controller, accessed on July 25, 2010.

\section{BIOGRAPHIES}

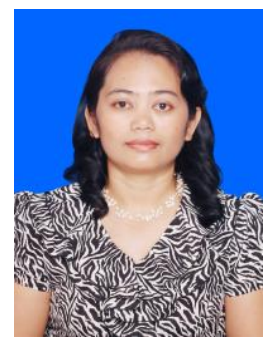

\section{Hestikah Eirene Patoding}

Was born in Palopo, April 7, 1971. The author graduated from Postgraduate Electrical Engineering at the University of Hasanuddin, Makassar, Indonesia. Has produced several scientific papers / research, among others, research Optimization Placement of Capacitors
Electrical System in Sulselbar As An Alternative Energy Using Genetic Algorithm (2012/as chairman) and Modeling Control of Automatic Voltage Regulator with a Proportional Integral Derivative to Changes Reactive Loads System in the in Gas Power Plant (2014/as chairman). The author is also as a speaker at national and international seminars.

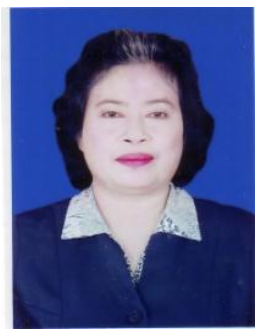

\section{Eodia T. Sedan Lobo'}

Was born in Rantepao, January 31, 1956. The author graduated from Postgraduate Electrical Engineering at the University of Hasanuddin, Makassar, Indonesia. Has produced scientific papers / research that is research Modeling Control of Automatic Voltage Regulator (AVR) with a Proportional Integral Derivative (PID) to Changes Reactive Loads System in the in Gas Power Plant (2014/as members) (2014 / as Members). As a speaker at national seminar.

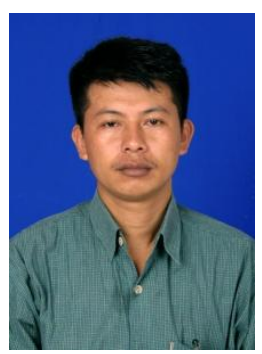

Matius Sau'

Was born in Tumbang Datu, July 7, 1975. The author graduated from Postgraduate Electrical Engineering in Power System field at the Bandung Institute of Technology. Has produced several scientific papers / research, among others, research Electrical Fields Biological Impacts Control System Along High Voltage Air Transmission Line of South Sulawesi Systems (Cases: Tello-Pangkep and TelloSungguminasa Tansmission System) (2012/as chairman). The author is also as a speaker at national and international seminars. 